\title{
Environmental monitoring and risk assessment of the soil pollution around two cement factories in EL-Minia Governorate, Egypt.
}

\author{
Hassan Hassan, Mahmoud Morsy, Gamal El-Dawwy, Kawther Haron Mohammed ${ }^{*}$ \\ Department of Soil Sciences, Faculty of Agriculture, Minia University, 61519 Minia, Egypt \\ * Correspondence: kawtherharon@mu.edu.eg; Tel: +2 01063455155; Fax: +20 862362182
}

\section{Article information}

Received: 19 March 2020

Revised: 16 April 2020

Accepted: 17 April 2020

\section{Key words}

Cement Kiln Dust

Lead

Nickel

Cadmium

Soil pollution

\begin{abstract}
Cement Kiln Dust (CKD), a by-product dust, is generated in large quantities during the manufacture of the cement. The fine particles of dust can be inhaled along with air and cause pollution to the soil around the cement factories. ElMinia Governorate, Egypt contains two cement factories. The first produces the white cement and the second produces the black cement. To environmentally monitor the soil pollution in the two studied areas, soil sampling was carried out in the Northern, Southern, Eastern, and Western directions around each cement factory. Soil samples were taken at six different monitoring distances away from each cement factory which are: $50 \mathrm{~m}, 100 \mathrm{~m}, 500 \mathrm{~m}, 1 \mathrm{~km}, 5 \mathrm{~km}$, and $10 \mathrm{~km}$. The values of $\mathrm{EC}, \mathrm{PH}, \mathrm{Pb}, \mathrm{Ni}$, and $\mathrm{Cd}$ of each site of the studied four directions around the two cement factories were decreased by increasing the monitoring distance from $50 \mathrm{~m}$ up to $10 \mathrm{~km}$ away from each studied cement factory. The electrical conductivity values of the top soil of the monitoring points were ranged between non-saline and very slightly saline. The PH values of the top soil of the monitoring points were ranged between neutral and moderately alkaline. The values of lead, nickel, and cadmium of the top soil of the monitoring points were below the allowable concentrations in the arable soil. This indicated that concentration of lead, nickel, and cadmium in the top soil around the two cement factories still in a safe level.
\end{abstract}

\section{Introduction}

In Egypt, production of the different types of cement reached nearly 30 million tons, with 3 million tons CKD/years in dry lines. It has been used in many different economical and beneficial applications in different parts of the world. Its pollutions have been found to be a problem around cement factories. It may contain hazardous compounds that pose harmful effects to the environment. Therefore, the cement kiln dust should be managed properly to avoid its harmful effects on humans, animals, and plants.

Olowoyo et al. (2015) pointed out that quality of the environment is vital for sustainable development, especially in the face of rapid developmental programs from developing countries.

In Egypt, production of the different types of cement reached nearly 30 million tons, with 3.0 million tons CKD/year in dry lines (Abd El-Aleem et al., 2005).

Cement kiln dust, a by-pass dust, is generated in large quantities during the production of the Portland cement (Abd El-Aleem $\boldsymbol{e t}$ al., 2005 and Kunal et al., 2012). Cement kiln dust is a fine powdery material of grey to can in color, relatively uniform in size, and similar in appearance to Portland cement.

The fine particles of dust can be inhaled along with air and in course of time cause respiratory problems in people living near and working in the factory.
The disposal of the fine kiln dust is very difficult and poses an environmental threat. To overcome this problem, research is being carried out in different parts of the world to find out economical and efficient ways and means of using cement kiln dust in various applications (Adaska and Taubert, 2008 and Rahman et al., 2011).

CKD presence in open atmosphere for a long period may have significant effect on the environment.

Lead $(\mathrm{Pb})$ has many interesting physio-chemical properties that make it a very useful heavy metal. Industrialization, urbanization, mining, and many other anthropogenic activities have resulted in the redistribution of lead from the earth's crust to the soil and to the environment (Pourrut et al., 2011).

Nickel pollution is a serious environmental concern. Nickel is strongly phototoxic at higher concentration (Bhalerao et al., 2015).

Cadmium has become one of the most harmful and widespread pollutants in agricultural soil, and soil-plant-environment system. Significant quantities of $\mathrm{Cd}$ have been added to soils globally due to various anthropogenic activities, posing a serious threat to safe food production and human health (Dong et al., 2007).

Nowadays, spread out pollution of soils by heavy metals is a major environmental problem throughout the world (Shniazi, 2012). Mandal and Voutchkov (2011) showed that the mental concentrations of top soils can be used as a powerful 
geochemical tool for monitoring the impact of anthropogenic activities.

Keeping in mind the prevailing scientific facts and results all over the world, the main objectives of this study are: (1) to characterization and evaluate the possibility of utilizing the white and black cement kiln dust in different economical and beneficial applications; (2) to investigate the impact of the white and black cement kiln dust on the soil salinity, soil $\mathrm{pH}$, and spatial distribution of lead, nickel, and cadmium in the soil around the Royal El-Minya cement factory and ASEC Minya cement factory located in El-Minia Governorate; and (3) to assess and monitor the soil salinity build up, change in the soil $\mathrm{pH}$, and pollution risk for lead, nickel, and cadmium in the soil around the two local cement factories.

\section{Materials and methods}

\subsection{Study area description}

The current study was carried out at two areas located in El-Minia Governorate, Egypt. The first area is the Seryrhia village, Samalout Center, El-Minia Governorate which is situated around the Royal El-Minia cement factory (RECF); however; the second area is the Beni Khaled village, Samalout Center, El-Minia Governorate which is situated around the ASEC Minia cement factory (AMCF).

Royal El-Minia Cement Company is a full owned Egyptian cement company working in the field of producing white cement. However, ASEC Minia Cement factory has officially commenced production of black cement at its ASEC Minia cement plant in El-Minia Governorate

\subsection{Cement Kiln Dust}

\subsubsection{Cement kiln dust sampling}

In order to know better about the quality of white and black cement kiln dust, the white cement kiln dust sample was obtained from the Royal El-Minia cement factory, while the black cement kiln dust sample was obtained from the ASEC Minai cement factory. The collected cement kiln dust samples were stored in polyethylene bags and were moved to the laboratory in order to perform the laboratory analysis procedures.

\subsubsection{Cement kiln dust preparation}

The white and black cement kiln dust samples were air dried at $105{ }^{\circ} \mathrm{C}$ for 24 hours in the laboratory, followed by grinding with mortar and pestle, and sieved to pass a $2.0 \mathrm{~mm}$ stainless steel sieve and further sieved to pass a $0.15 \mathrm{~mm}$ sieve for the analysis.

\subsubsection{Chemical analysis of the cement kiln dust}

The chemical analysis of the white and black cement kiln dust samples was undertaken according to the standard frequently used methods. Some chemical properties of the white and black cement kiln dust are shown in (Table 1).
Table 1: Some chemical properties of the white and black cement kiln dusts

\begin{tabular}{|c|c|c|c|}
\hline \multicolumn{2}{|c|}{ Chemical properties of CKD } & Black CKD & White CKD \\
\hline \multicolumn{2}{|c|}{$\mathrm{EC}\left(\mathrm{dS} \mathrm{m^{-1 }}\right)$} & 14.28 & 7.99 \\
\hline \multicolumn{2}{|c|}{${ }_{P}^{H}(1: 2.5$ extract $)$} & 11.70 & 6.89 \\
\hline \multirow{5}{*}{$\begin{array}{l}\text { Soluble } \\
\text { cations }\end{array}$} & $\mathrm{Na}^{+}\left(\mathrm{mg} \mathrm{kg}^{-1}\right)$ & 5.80 & 3.76 \\
\hline & $\mathbf{K}^{+}\left(\mathbf{m g ~ k g}^{-1}\right)$ & 4.50 & 1.09 \\
\hline & $\mathrm{Ca}^{2+}\left(\mathrm{mg} \mathrm{kg}^{-1}\right)$ & 1.20 & 4.51 \\
\hline & $\mathrm{Mg}^{2+}\left(\mathrm{mg} \mathrm{kg}^{-1}\right)$ & 4.20 & 3.12 \\
\hline & $\mathrm{Cl}^{-}\left(\mathrm{mg} \mathrm{kg}^{-1}\right)$ & 55.10 & 13.00 \\
\hline \multirow{4}{*}{$\begin{array}{c}\text { Soluble } \\
\text { anions }\end{array}$} & $\mathrm{HCO}_{3}^{-}\left(\mathrm{mg} \mathrm{kg}^{-1}\right)$ & 0.00 & 0.00 \\
\hline & $\mathrm{CO}_{3}{ }^{2-}\left(\mathrm{mg} \mathrm{kg}^{-1}\right)$ & 6.10 & 4.98 \\
\hline & $\mathrm{SO}_{4}{ }^{2-}\left(\mathrm{mg} \mathrm{kg}^{-1}\right)$ & 15.50 & 4.45 \\
\hline & $\mathrm{Pb}\left(\mathrm{mg} \mathrm{kg}^{-1}\right)$ & 15.62 & 9.73 \\
\hline \multirow{2}{*}{$\begin{array}{l}\text { Heavy } \\
\text { metals }\end{array}$} & $\mathrm{Ni}\left(\mathrm{mg} \mathrm{kg}^{-1}\right)$ & 6.16 & 3.62 \\
\hline & $\mathrm{Cd}\left(\mathrm{mg} \mathrm{kg}^{-1}\right)$ & 4.79 & 2.10 \\
\hline
\end{tabular}

\subsection{Soil}

\subsection{Soil sampling}

To environmentally monitor the soil pollution in the two studied areas, soil sampling was carried out in the Northern, Southern, Eastern, and Western directions around each cement factory. Soil samples were collected from four monitoring points around each cement factory. Each monitoring point represents the site of each direction around each cement factory. Soil samples were taken at six different monitoring distances away from each cement factory; which are: $50 \mathrm{~m}, 100 \mathrm{~m}, 500$ $\mathrm{m}, 1.0 \mathrm{~km}, 5 \mathrm{~km}$, and $10.0 \mathrm{~km}$.

The soil samples were taken from the top soil at the depth of 0.0 - $15 \mathrm{~cm}$ using a hand auger. The soil samples were homogenized by the quartering method. The collected soil samples were stored in polyethylene bags and were moved to the laboratory in order to perform the laboratory analysis procedures.

\subsubsection{Chemical analysis of the soil}

Chemical analysis of the top of soil samples collected from current studied two areas has been carried out as follows:

1- The soil electrical conductivity was measured in a soil past extract using the E.C. meter as described by Page $\boldsymbol{e t}$ al. (1982).

2- The soil $\mathrm{pH}$ was measured in a soil-water suspension (Ratio 1:2.5) using the $\mathrm{pH}$ meter as described by Jackson (1973).

3- Lead, nickel, and cadmium were determined in the digested solution of soil using the Atomic Absorption 
Spectrophotometer (EAAS) as described by (ISO 11047, 1998)

\subsection{Soil pollution risk assessment}

Risk assessment of the soil pollution is one of the key pathways when investigating the risk of white and black cement kiln dusts on the soil, human health, and surrounding ecosystem.

The soil pollution risk assessment was performed using the following international guidelines:

1- Guidelines for soil salinity classes as proposed by Scianna (2002) from the United States of America.

2- Guidelines for soil $\mathrm{pH}$ classes as proposed by Scianna (2002) from the United States of America.

3- Guidelines of allowable concentrations of certain elements in the arable soil as proposed by Kloke (1982) from the Federal Republic of Germany. \{Lead(100ppm)Nickel(50ppm)- Cadmium(3ppm)\}

4- Guidelines of Indian standards of heavy metals in the soil as proposed by Awashthi (2000) from India. \{Lead (250500ppm) - Nickel(75-150ppm) - Cadmium(3-6ppm)

5- Guidelines of allowable limits of heavy metals concentrations in the soil as proposed by ECDGE (2010) from Netherlands and proposed by Wang et al. (2012) from China. \{Lead (100ppm) -Nickel(250ppm)Cadmium(350ppm)\}.

\section{Results and discussion}

\subsection{Quality and management of the white and black cement kiln dusts}

The chemical analysis of the white and black cement kiln dusts is presented in (Table 1). It is evident from the results in Table 1 that the white and black CKDs have high values of the electrical conductivity $\left(7.99 \mathrm{dSm}^{-1}\right.$ and $14.28 \mathrm{dSm}^{-1}$, respectively).

The electrical conductivity value of black CKD was higher than that of the white CKD.

The white and black CKDs have low value of sodium, potassium, calcium, and magnesium concentrations. Calcium is the dominant cation followed by sodium and magnesium cations in the white CKD, whereas, sodium is the dominant cations followed by potassium and magnesium cations in the black CKD.

The white CKD has relatively low value of chloride, sulphate, and carbonate concentration. However, the black CKD has a relatively high value of chloride concentration as well as it has low value of sulphate and carbonate concentration.

The chloride, sulphate, and carbonate concentration of black CKD was higher than that of white CKD.

The white CKDs was approximately in neutral $\mathrm{pH}(\mathrm{pH} 6.89)$, implying that the use of white CKD in the agricultural applications such as a soil amendment and a fertilizer material will not cause a nutritional imbalance in the soil and plants and will not effect on the surrounding ecosystem.

The black CKD was in the alkaline $\mathrm{pH}$ ( $\mathrm{pH}$ 11.70), suggesting that the use of black CKD in the agricultural applications such as a soil amendment and a fertilizer material will cause a nutritional imbalance in the soil and plants and will effect on the surrounding ecosystem.

The lead, nickel, and cadmium concentration of black CKD was higher than that of white CKD. Indicating that the use of white and black CKDs in agricultural application such as soil amendment and a fertilizer material will not have toxic effects on plants, animals, and human health. Consequently, the white and black CKDs are considered to be safe natural materials in terms of this concern.

According to the guidelines of ECDGE (2010) and Wang et al. (2012) the concentration of lead, nickel, and cadmium in the white and black CKDs is below the allowable limits of lead, nickel, and cadmium concentration in the soil.

Many researchers have observed that the chemical, physical, and mineralogical property of the cement kiln dust varies from one factory to another. These properties of CKD depend on the kind of raw materials used, type of kiln operation, dust collection method employed at a particular cement plant, overall equipment layout, type of cement being used, and type of fuel used in the plant (Naik et al., 2003; Abd El-Aleem et al. 2005; and Kunal et al., 2012).

Scianna (2002) pointed out that ions such as $\mathrm{Na}$ can influence the soil chemistry and biology to such a degree as to limit the plant nutrient availability.

Adaska and Taubert (2008) indicated that because potassium is the most valuable fertilizer element contained in the dust and the least desirable element for recycling, CKD with high potassium contents could be adequately utilized as a fertilizer. The sodium, potassium, and magnesium concentration of black CKD was higher than that of the white CKD.

Rahman et al. (2011) indicated that the application of CKD to the agricultural land can increase the $\mathrm{pH}$ of the soils, reduce function of $\mathrm{pH}$ in the soils, and as a result reduce the plant and root stress.

According to the guidelines of Kloke (1982), and Awashthi (2000) the concentration of lead and nickel in the white and black CKDs is below the allowable concentration of lead and nickel in the arable soil. Cadmium concentration in the white CKD is below the allowable concentration of cadmium in the arable soil; however, cadmium concentration in the black CKD is above the allowable concentration of cadmium in the arable soil.

\subsection{Environmental monitoring and risk assessment of the soil pollution around the studied two cement factories}

\subsubsection{Soil salinity build up around the studied two cement factories}




\subsubsection{Impact of the white and black cement kiln dusts on the soil salinity}

The electrical conductivity of top soil $(0.0-15.0 \mathrm{~cm})$ of each site of the studied four directions around the RECF and around the $\mathrm{AMCF}$ was decreased by increasing the monitoring distance from $50 \mathrm{~m}$ up to $10 \mathrm{~km}$ away from each studied cement factory as presented in (Table 2) and illustrated in (Figure 1). The decrease in the soil electrical conductivity may be attributed to the dilution effect Along the six monitoring points away from the RECF, the value of soil electrical conductivity ranged from $1.50 \mathrm{dS} \mathrm{m}^{-1}$ to $3.02 \mathrm{dS} \mathrm{m}^{-1}$ in each of four directions. However, along the six monitoring points away from the AMCF, the value of soil electrical conductivity ranged from $2.08 \mathrm{dS} \mathrm{m}^{-1}$ to 3.95 $\mathrm{dS} \mathrm{m} \mathrm{m}^{-1}$ in each site of four directions.

The values of soil electrical conductivity in each site of four directions around the ASEC Minia cement factory were higher than those of each same site of four directions around the Royal El-Minia cement factory. One explanation for this result is that the electrical conductivity value of black cement kiln dust (14.28 $\mathrm{dS} \mathrm{m}^{-1}$ ) was higher than that of the white cement kiln dust (7.99 $\left.\mathrm{dS} \mathrm{m}^{-1}\right)$ as given in (Table 1).

\subsubsection{Risk assessment of the soil salinity around the studied two cement factories}

It is obvious from the results from Table 2 that at each monitoring point of each respected monitoring distance away from the RECF, the electrical conductivity of top soil of each site of four directions was decreased from the highest to the lowest in the following descending order: Eastern direction > Western direction > Northern direction > Southern direction. According to the guidelines of Scianna (2002), the electrical conductivity value of top soil of some monitoring points of each site of four directions around the RECF is within the range of 0.0-2.0 dS $\mathrm{m}^{-1}$ under the salinity class of "non- saline", indicating that these sites are classified as non-saline sites (safe soil salinity sites). Therefore, the electrical conductivity value of top soil of these sites has no salinity hazard. While, the electrical conductivity value of top soil of other monitoring points of each site of four directions around the RECF is within the range of 2.0-4.0 dS m$~^{-1}$ under the salinity class of "very slightly saline", Scianna (2002) reported that even soils classified as "slightly saline" are marginally acceptable for many crops.

Table 2: Effect of the white and black cement kiln dusts on the soil salinity $\left(\mathrm{EC}, \mathrm{dSm}^{-1}\right)$ around the studied two cement factories

\begin{tabular}{|c|c|c|c|c|c|c|c|c|}
\hline \multirow{2}{*}{ Factories } & \multirow{2}{*}{ Directions } & \multicolumn{7}{|c|}{ Distances } \\
\hline & & $50 \mathrm{~m}$ & $100 \mathrm{~m}$ & $500 \mathrm{~m}$ & $1.0 \mathrm{~km}$ & $\begin{array}{ll}5 & \mathrm{~km} \\
\end{array}$ & $10 \mathrm{~km}$ & Mean \\
\hline \multirow{5}{*}{ 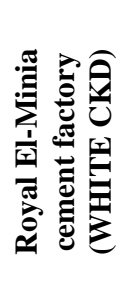 } & Northern & 3.00 & 2.50 & 2.20 & 2.80 & 1.90 & 1.80 & 2.37 \\
\hline & Southern & 3.02 & 2.54 & 2.50 & 1.99 & 1.90 & 1.50 & 2.24 \\
\hline & Eastern & 2.89 & 2.88 & 2.89 & 2.70 & 1.98 & 1.95 & 2.55 \\
\hline & Western & 2.99 & 2.80 & 2.80 & 2.20 & 1.99 & 1.99 & 2.46 \\
\hline & Mean & 2.97 & 2.68 & 2.60 & 2.42 & 1.94 & 1.81 & \\
\hline \multirow{5}{*}{ 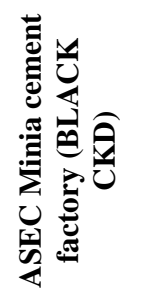 } & Northern & 3.95 & 3.80 & 3.75 & 3.20 & 2.78 & 2.10 & 3.26 \\
\hline & Southern & 3.98 & 3.81 & 3.72 & 3.22 & 2.75 & 2.15 & 3.27 \\
\hline & Eastern & 3.92 & 3.78 & 3.70 & 3.25 & 2.70 & 2.08 & 3.24 \\
\hline & Western & 3.92 & 3.77 & 3.68 & 3.26 & 2.70 & 2.13 & 3.24 \\
\hline & Mean & 3.94 & 3.79 & 3.71 & 3.23 & 2.73 & 2.12 & \\
\hline
\end{tabular}

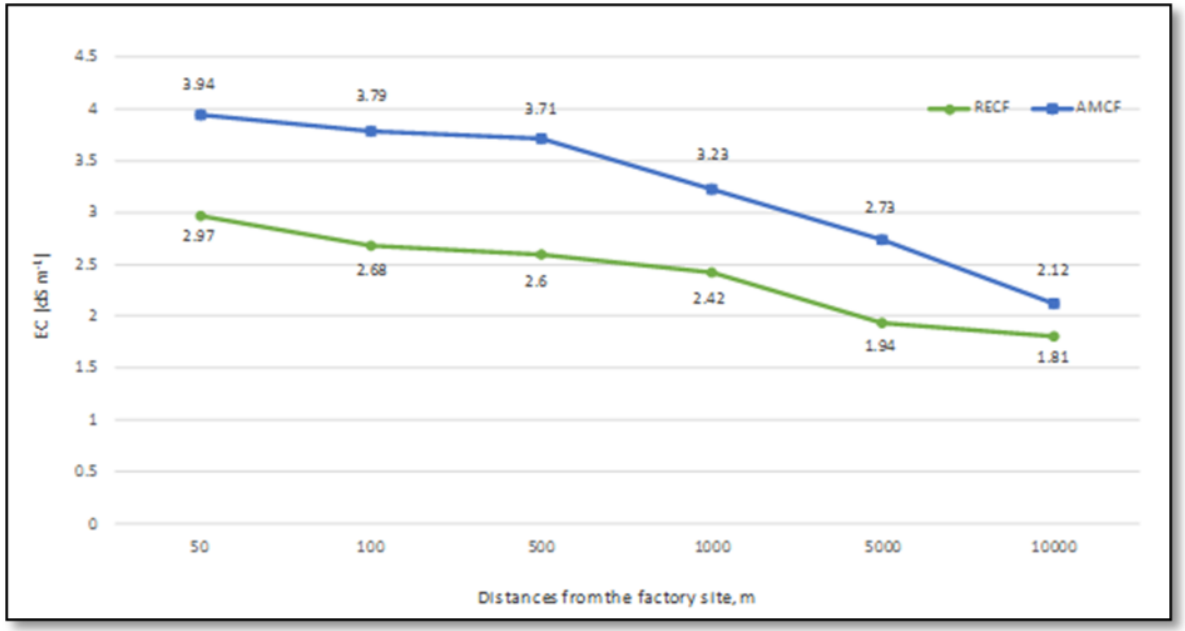

Figure 1: Spatial distribution of the mean value of soil EC around the two cement factories 
The lowest value of soil electrical conductivity $\left(1.50 \mathrm{dS} \mathrm{m}^{-}\right.$ $\left.{ }^{1}\right)$ was obtained in the site of Southern direction around the RECF at a monitoring distance of $10 \mathrm{~km}$ away from each studied cement factory.

In contrary, the highest value of soil electrical conductivity (3.95 $\mathrm{dS} \mathrm{m}^{-1}$ ) was recorded in the site of Northern direction around the AMCF at a monitoring distance of $50 \mathrm{~m}$ away from each studied cement factory.

\subsubsection{Soil $\mathbf{P}^{\mathrm{H}}$ around the studied two Cement Factories}

\subsubsection{Impact of the White and Black Cement Kiln Dusts on the soil $\mathbf{P}^{\mathrm{H}}$}

The soils were all approximately in the neutral $\mathrm{PH}$ in each site of four directions across the six monitoring distances away from the RECF. While, the soils were ranged approximately between the natural $\mathrm{PH}$ and alkaline $\mathrm{P}^{\mathrm{H}}$ in each sites of four directions along the six monitoring distances away from the AMCF as shown in (Table3).

The $\mathrm{P}^{\mathrm{H}}$ of top soil of each site of four directions around the RECF was slightly decreased due to increasing the monitoring distance from $50 \mathrm{~m}$ up to $10 \mathrm{~km}$ away from the RECF. Moreover, the PH of top soil of each site of four directions around the AMCF was decreased when the monitoring distance was increased from $50 \mathrm{~m}$ up to $10 \mathrm{~km}$ away from the AMCF. The decreased in the soil $\mathrm{P}^{\mathrm{H}}$ may be explained by the dilution effect. Across the six monitoring points away from the RECF, the value of soil $\mathrm{PH}$ ranged from 7.07 to 7.17 in each site of four directions. Whereas, across the six monitoring points away from the $\mathrm{AMCF}$, the value of soil $\mathrm{P}^{\mathrm{H}}$ ranged from 7.15 to 7.95 in each site of four directions.

There were slightly differences in the value of soil $\mathrm{P}^{\mathrm{H}}$ between the points of six monitoring distances away from the RECF, however, there were the points of six monitoring distances away from the AMCF. In addition, there were slight differences in the value of soil $\mathrm{P}^{\mathrm{H}}$ between the four directions around each studied cement factory.
The values of soil $\mathrm{P}^{\mathrm{H}}$ in each site of four directions around the ASEC Minia cement factory were slightly higher than those of each some site of four directions around the Royal El-Minia cement factory. This result may be interpreted by that the $\mathrm{P}^{\mathrm{H}}$ value of black cement kiln dust (11.70) was higher than that of the white cement kiln dust (6.89) as presented in (Table 1). Rahman et al. (2011) pointed out that the application of CKD to agriculture land can increase the $\mathrm{PH}$ of the soils, reduce function of $\mathrm{PH}$ in the soils, and as a result reduce plant and root stress.

\subsubsection{Risk assessment of the soil $\mathbf{P}^{\mathrm{H}}$ around the studied two cement factories}

Regarding the risk assessment of soil $\mathrm{P}^{\mathrm{H}}$ around the studied two cement factories, all the values provided in (Table 3) were compared with the guidelines for the soil $\mathrm{P}^{\mathrm{H}}$ classes proposed by Scianna (2002). According to the guidelines of Scianna (2002), the $\mathrm{P}^{\mathrm{H}}$ value of top soil in each site of four directions around the RECF is within the range of 6.6-7.3 under the $\mathrm{P}^{\mathrm{H}}$ class of "neutral" indicating that these sites are classified as neutral $\mathrm{P}^{\mathrm{H}}$ sites (safe soil $\mathrm{P}^{\mathrm{H}}$ sites). Consequently, the $\mathrm{P}^{\mathrm{H}}$ value of top soil of these sites has no alkalinity hazard.

The $\mathrm{P}^{\mathrm{H}}$ value of top soil of some monitoring points of each site of four directions around the AMCF is within the range of 7.47.8 under the $\mathrm{P}^{\mathrm{H}}$ class of "slightly alkaline". Suggesting that these sites are classified as slightly alkaline $\mathrm{P}^{\mathrm{H}}$ sites. While, the $\mathrm{P}^{\mathrm{H}}$ value of top soil of other monitoring points of each site of four directions around the AMCF is within the range of 7.9-8.4 under the $\mathrm{P}^{\mathrm{H}}$ class of "moderately alkaline", indicating that these sites are classified as moderately alkaline $\mathrm{P}^{\mathrm{H}}$ sites.

The lowest value of soil $\mathrm{P}^{\mathrm{H}}$ (7.07) was obtained in the site of Eastern directions around the RECM at two monitoring distances of $5.0 \mathrm{~km}$ and $10 \mathrm{~km}$ as well as in the site of Western directions around the RECM at a monitoring distance of $1.0 \mathrm{~km}$. Therefore, the $\mathrm{P}^{\mathrm{H}}$ value of top soil of these sites has no alkalinity hazard.

Table 3: Effect of the white and black cement kiln dusts on the soil $\mathrm{p}^{\mathrm{H}}$ around the studied two cement factories

\begin{tabular}{cccccccc}
\hline & Directions & \multicolumn{7}{c}{ Distances } \\
\cline { 3 - 8 } Factories & Northern & 7.17 & 7.15 & 7.13 & 7.09 & 7.09 & 7.08 \\
\hline & Southern & 7.15 & 7.15 & 7.12 & 7.10 & 7.10 & 7.09 \\
\hline & Eastern & 7.16 & 7.14 & 7.13 & 7.11 & 7.07 & 7.07 \\
\hline & Western & 7.15 & 7.15 & 7.14 & 7.07 & 7.08 & 7.08 \\
& Northern & 7.93 & 7.84 & 7.72 & 7.50 & 7.32 & 7.15 \\
& Southern & 7.92 & 7.85 & 7.72 & 7.50 & 7.33 & 7.15 \\
& Eastern & 7.93 & 7.81 & 7.71 & 7.52 & 7.30 & 7.18 \\
\hline & Western & 7.95 & 7.84 & 7.75 & 7.49 & 7.35 & 7.17 \\
\hline
\end{tabular}


In contrast, the highest value of soil $\mathrm{P}^{\mathrm{H}}$ (7.95) was recorded in the site of Western direction around the AMCM at a monitoring distance of $50 \mathrm{~m}$ away from studied cement factory. The highest values of soil $\mathrm{PH}$ may be because of its probable source from the carryover of cement kiln dust emitted from the RECM and AMCM since the monitoring point at $50 \mathrm{~m}$ is very close to each studied cement factory.

\subsubsection{Lead in the soil around the studied two cement factories}

\subsubsection{Impact of the white and black cement kiln dust on the spatial distribution of lead in the soil}

The lead concentration in the top soil of each site of four directions around the RECF and around the AMCF was decreased as a result of increasing the monitoring distance from $50 \mathrm{~m}$ up to $10 \mathrm{~km}$ away from each studied cement factory as presented in (Table 4) and illustrated in (Figure 2). The decrease in the lead concentration in the soil may be due to the dilution effect since lead origination from the cement kiln dust of industrial activities.
It can be seen from the results in (Table 4) that considerable differences in the value of lead concentration in the soil were noticed between the points of six monitoring distances away from the RECF and AMCF. Whereas, slight differences in the value of lead concentration in the soil were observed between the four directions around each studied cement factory.

At each monitoring point of each respected monitoring distances away from each studied cement factory, the values of lead concentration in the soil of each site of four directions around the ASEC Minia cement factory were higher than those of each same site of four directions around the Royal El-Mnia cement factory. This result may be explained by that lead concentration value of black cement kiln dust $\left(15.62 \mathrm{mgkg}^{-1}\right)$ was higher than that of the white cement kiln dust $\left(9.73 \mathrm{mgkg}^{-1}\right)$ as listed in (Table 1)

\subsubsection{Accumulation and risk assessment of the lead concentration in the soil around the studied two cement factories}

It is evident from the results in Table 4 that the lead concentration in the soil of each site of four directions around

Table 4: Effect of the white and black cement kiln dusts on the spatial distribution of lead in the soil around the studied two cement factories

\begin{tabular}{|c|c|c|c|c|c|c|c|c|}
\hline \multirow{2}{*}{ Factories } & \multirow{2}{*}{ Directions } & \multicolumn{7}{|c|}{ Distances } \\
\hline & & $50 \mathrm{~m}$ & $100 \mathrm{~m}$ & $500 \mathrm{~m}$ & $1.0 \mathrm{~km}$ & $5 \mathrm{~km}$ & $10 \mathrm{~km}$ & Mean \\
\hline \multirow{5}{*}{ 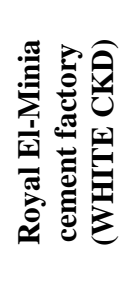 } & Northern & 5.40 & 3.50 & 1.80 & 1.10 & 0.70 & 0.10 & 2.10 \\
\hline & Southern & 5.60 & 3.40 & 2.00 & 1.80 & 0.75 & 0.12 & 2.28 \\
\hline & Eastern & 5.44 & 3.35 & 2.10 & 1.50 & 0.72 & 0.10 & 2.20 \\
\hline & Western & 5.50 & 3.30 & 1.99 & 1.10 & 0.69 & 0.09 & 2.11 \\
\hline & Mean & 5.49 & 3.39 & 1.97 & 1.38 & 0.72 & 0.103 & \\
\hline \multirow{5}{*}{ 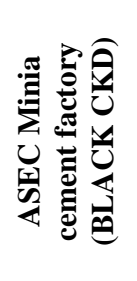 } & Northern & 6.54 & 5.43 & 2.02 & 1.50 & 0.75 & 0.14 & 2.48 \\
\hline & Southern & 6.60 & 5.40 & 2.50 & 1.53 & 0.76 & 0.15 & 2.82 \\
\hline & Eastern & 6.69 & 5.54 & 2.70 & 1.80 & 0.79 & 0.15 & 2.95 \\
\hline & Western & 6.68 & 5.50 & 2.67 & 1.78 & 0.80 & 0.17 & 2.93 \\
\hline & Mean & 6.63 & 5.47 & 2.47 & 1.65 & 0.78 & 0.15 & \\
\hline
\end{tabular}

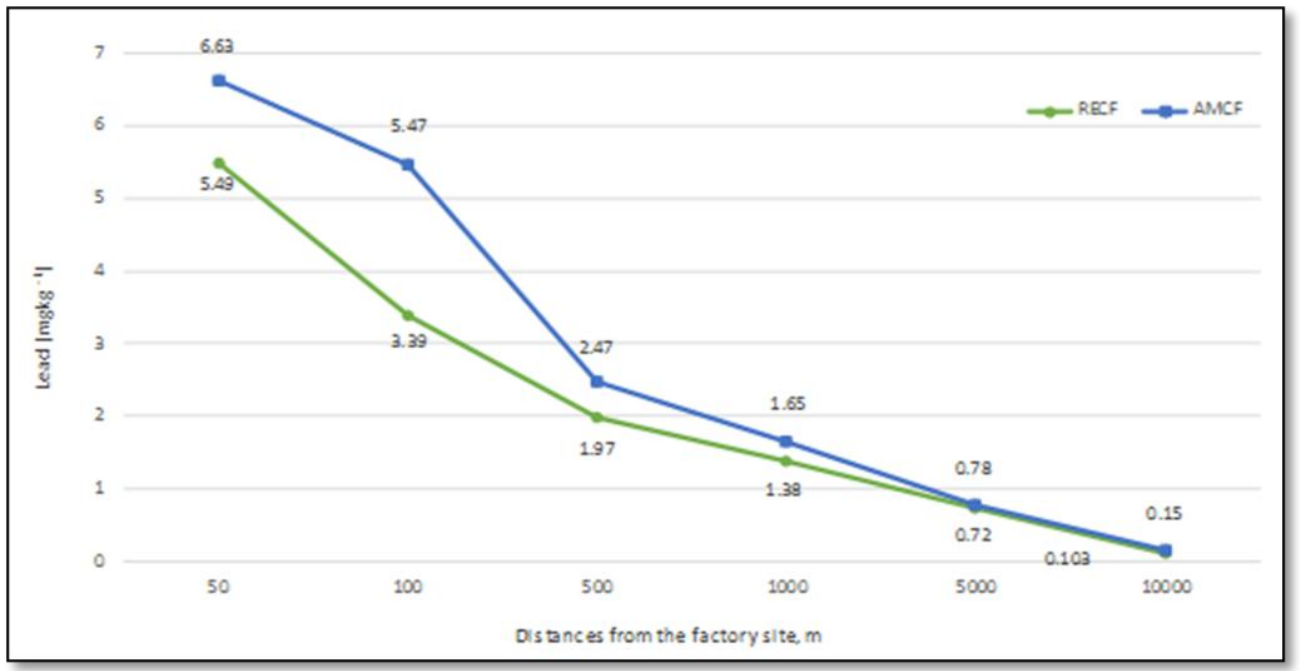

Figure 2: Spatial distribution of the mean value of soil $\mathrm{Pb}$ around the two cement factories 
the RECF was decreased from the highest to the lowest in the following descending order: Southern direction $>$ Eastern direction $>$ Western direction $>$ Northern direction. However, the lead concentration in the soil of site each four directions around the AMCF was decreased from the highest to the lowest in the following descending order: Eastern direction $>$ Western direction $>$ Southern direction $>$ Northern direction.

Concerning the risk assessment of lead concentration in the soil around the studied two cement factories, all the values shown in Table 4 were compared with the international guidelines for the allowable limits of heavy metal concentration in the soil.

All the values shown in (Table 4) were compared with the tested guidelines of Kloke (1982), Awashthi (2000), ECDGE (2010), and Wang et al. (2012). The values of lead concentration in the top soils are below the allowable concentration of lead in the arable soil. Indicating that no there is obvious lead pollution in the top soils. Therefore, each site of the four directions around the RECF and AMCF is still in a safe lead level.

The lowest value of lead concentration in the soil $\left(0.09 \mathrm{mgkg}^{-1}\right)$ was obtained in the site of Western direction around the RECF at a monitoring distance of $10 \mathrm{~km}$ away from cement factory. The lowest values of lead concentration in the soil may be explained by dilution effect because of the very long distance $(10 \mathrm{~km})$ between the monitoring point at a distance of $10 \mathrm{~km}$ and each studied cement factory.

According to the international guidelines the site of Western direction around the RECF and the site of Northern direction around the $\mathrm{AMCF}$ at a monitoring distance of $10 \mathrm{~km}$ are classified as safe lead level sites.
On the other hand, the highest value of lead concentration in the soil $\left(6.69 \mathrm{mgkg}^{-1}\right)$ was recorded in the site of Eastern direction around the AMCF at a monitoring distance of 50m away from cement factory. The highest values of lead concentration in the soil may be as a result of the carryover of cement kiln dust emitted from the RECF and AMCF since the monitoring point at a distance of $50 \mathrm{~m}$ is very close to each studied cement factory.

\subsubsection{Nickel in the soil around the studied two cement factories}

\subsubsection{Impact of the white and black cement kiln dusts on the spatial distribution of nickel}

The nickel concentration in the top soil of each site of four directions around the RECF and around the AMCF was decreased with increasing the monitoring distance from 50m up to $10 \mathrm{~km}$ away from each studied cement factory as provided in Table 5 and illustrated in (Figure 3). The decrease in the nickel concentration in the soil may be attributed to the dilution effect since as the monitoring distance becomes long, the anthropogenic emissions such as the cement kiln dust coming from the RECF and AMCF become low.

Across the six monitoring points away from the RECF, the value of nickel concentration in the soil ranged from $1.28 \mathrm{mgkg}$ ${ }^{1}$ to $2.61 \mathrm{mgkg}^{-1}$ in each site of four directions. Whereas, across the six monitoring points away from the AMCF, the value of nickel concentration in the soil ranged from $1.94 \mathrm{mgkg}^{-1}$ to 3.48 $\mathrm{mgkg}^{-1}$ in each site of four directions. It can be observed from these results that the top soils contained low concentrations of

Table5: Effect of the white and black cement kiln dusts on the spatial distribution of nickel in the soil around the studied two cement factories

\begin{tabular}{|c|c|c|c|c|c|c|c|c|}
\hline \multirow{2}{*}{ Factories } & \multirow{2}{*}{ Directions } & \multicolumn{7}{|c|}{ Distances } \\
\hline & & $50 \mathrm{~m}$ & $100 \mathrm{~m}$ & $500 \mathrm{~m}$ & $1.0 \mathrm{~km}$ & $5 \mathrm{~km}$ & $10 \mathrm{~km}$ & Mean \\
\hline \multirow{5}{*}{ 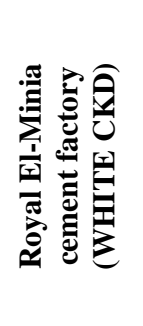 } & Northern & 2.50 & 2.00 & 1.69 & 1.50 & 1.44 & 1.43 & 1.76 \\
\hline & Southern & 2.61 & 2.10 & 1.68 & 1.48 & 1.33 & 1.32 & 1.75 \\
\hline & Eastern & 2.61 & 2.50 & 1.98 & 1.80 & 1.30 & 1.28 & 1.91 \\
\hline & Western & 2.55 & 2.12 & 1.50 & 1.48 & 1.36 & 1.33 & 1.72 \\
\hline & Mean & 2.57 & 2.18 & 1.71 & 1.57 & 1.36 & 1.34 & \\
\hline \multirow{5}{*}{ 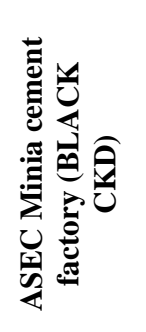 } & Northern & 3.48 & 3.10 & 3.01 & 2.56 & 2.10 & 1.95 & 2.70 \\
\hline & Southern & 3.45 & 3.12 & 3.02 & 2.61 & 2.10 & 1.95 & 2.71 \\
\hline & Eastern & 3.47 & 3.10 & 3.07 & 2.62 & 2.12 & 1.94 & 2.72 \\
\hline & Western & 3.47 & 3.13 & 3.06 & 2.60 & 2.13 & 1.95 & 2.72 \\
\hline & Mean & 3.47 & 3.11 & 3.04 & 2.60 & 2.11 & 1.95 & \\
\hline
\end{tabular}




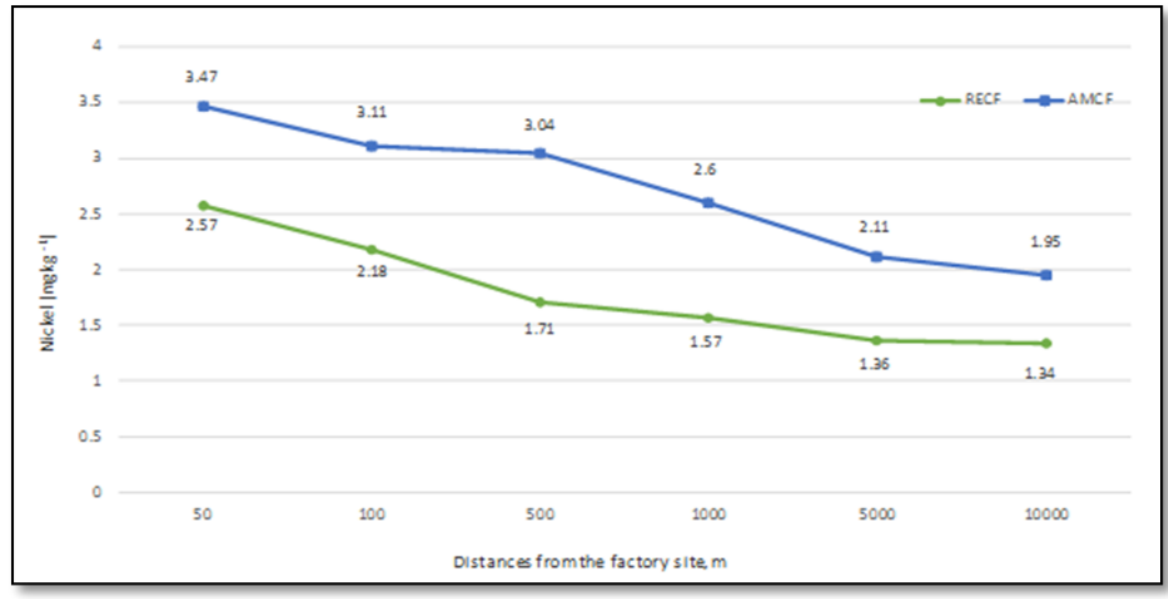

Figure 3: Spatial distribution of the mean value of soil Ni around the two cement factories

nickel in each site of four directions around the RECF and AMCF. Nickel is highly distributed in each site of four directions around each studied cement factory.

It is clear from the results summarized in (Table 5) that there were considerable differences in the value of nickel concentration in the soil between the points of six monitoring distance away from the RECF and AMCF. While, there were slight differences in the value of nickel concentration in the soil were noticed between the four directions around each studied cement factory.

At each monitoring point of each respected monitoring distance away from each studied cement factory, the values of nickel concentration in the soil of each site of four directions around the ASEC Minia cement factory were higher than those of each same site of four directions around the Royal El-Minia cement factory. One interpretation for this result is that the nickel concentration value of black cement kiln dust $\left(6.16 \mathrm{mgkg}^{-1}\right)$ was higher than that of the white cement kiln dust $\left(3.62 \mathrm{mgkg}^{-1}\right)$ as shown in (Table 1).

\subsubsection{Accumulation and risk assessment of the nickel concentration in the soil around the studied two cement factories}

Regarding the risk assessment of nickel concentration in the soil around the studied two cement factories, all the values listed in (Table 5) were compared with the used guidelines of. The values of nickel concentration in the top soils are below the allowable limit of nickel concentration in the soil implying that there is no evident nickel pollution in the top soils. The nickel concentration in the top soils has no risk, do not make a concern. Consequently, each site of the four directions around the RECF and AMCF is still in a safe nickel level.

According to the used guidelines, the site of Eastern direction around the RECF and AMCF at a monitoring distance of $10 \mathrm{~km}$ is classified as safe nickel level site.

In contrary, the highest value of nickel concentration in the soil (3.48 $\mathrm{mg} \mathrm{kg}^{-1}$ ) was recorded in the site of Northern direction around the $\mathrm{AMCF}$ at a monitoring distance of $50 \mathrm{~m}$ away from each studied cement factory.
The highest values of nickel concentration in the soil are below the allowable concentration of nickel in the arable soil according to the used guidelines. Thus, the site of Southern and Eastern direction around the RECF and the site of Northern direction around the AMCF at a monitoring distance of $50 \mathrm{~m}$ are classified as safe nickel level sites

\subsubsection{Cadmium in the soil around the studied two cement factories}

\subsubsection{Impact of the white and black cement kiln dusts on the spatial distribution of cadmium in the soil}

The cadmium concentration in the top soil of each site of four directions around the RECF and around the AMCF was decreased when the monitoring distance was increased from $50 \mathrm{~m}$ up to $10 \mathrm{~km}$ away from each studied cement factory as shown in (Table 6) and illustrated in (Figure 4).

Along the six monitoring points away from the RECF, the value of cadmium concentration in the soil ranged from $0.02 \mathrm{mgkg}^{-1}$ to $1.80 \mathrm{mgkg}-1$ in each site of four directions. However, along the six monitoring points away from the AMCF, the value of cadmium concentration in the soil ranged from $0.01 \mathrm{mgkg}^{-1}$ to $2.91 \mathrm{mgkg}^{-1}$ in each site of four directions. It is appeared from these results that the top soils contained low concentration of cadmium in each site of four directions around the RECF and AMCF. Cadmium is highly distributed in each site of four directions around each studied cement factory.

It is obvious from the results listed in (Table 6) that there were considerable differences in the value of cadmium concentration in the soil between the points of six monitoring distances away from the RECF and AMCF as well as between the four directions around the RECF. Whereas, there were slight differences in the value of cadmium concentration in the soil between the four directions around the AMCF.

At the monitoring point of the respected monitoring distances of $50 \mathrm{~m}, 100 \mathrm{~m}$, and $500 \mathrm{~m}$ away from each studied cement factory, the values of cadmium concentration in the soil of each site of four directions around the ASEC Minia cement factory were higher than those of each same site of four directions around the 
Royal El-Minia cement factory. This result may be explained by that the cadmium concentration value of black cement kiln dust $\left(4.79 \mathrm{mgkg}^{-1}\right)$ was higher than that of the white cement kiln dust $\left(2.10 \mathrm{mgkg}^{-1}\right)$ as given in (Table 1).

\subsubsection{Accumulation and risk assessment of the cadmium concentration in the soil around the studied two cement factories}

The cadmium concentration in the soil of each site of four directions around the RECF was decreased from the highest to the lowest in the following descending order: Northern direction> Eastern direction> Western direction> Southern direction. While there were slight differences in the mean value of cadmium concentration in the soil were noticed between the four directions around each studied cement factory.
Considering the risk assessment of cadmium concentration in the soil around the studied two cement factories, all the values presented in Table 6 were compared with the used guidelines. The values of cadmium concentration in the two soils are below the allowable concentration of cadmium in the arable soil. Therefore, each site of the four directions around the RECF and AMCF is still in a safe cadmium level.

It can be noticed from the results in Table 6 that the lowest value of cadmium concentration in the soil $\left(0.01 \mathrm{mgkg}^{-1}\right)$ was obtained in the site of Northern direction around the AMCF at a monitoring distance of $10 \mathrm{~km}$ away from cement factory.

On the other hand, the highest value of cadmium concentration in the soil $\left(2.91 \mathrm{mgkg}^{-1}\right)$ was recorded in the site of Eastern direction around the $\mathrm{AMCF}$ at a monitoring distance of $50 \mathrm{~m}$ away from studied cement factory.

Table 6: Effect of the white and black cement kiln dusts on the spatial distribution of cadmium in the soil around the studied two cement factories

\begin{tabular}{|c|c|c|c|c|c|c|c|c|}
\hline \multirow{2}{*}{ Factories } & \multirow{2}{*}{ Directions } & \multicolumn{7}{|c|}{ Distances } \\
\hline & & $50 \mathrm{~m}$ & $100 \mathrm{~m}$ & $500 \mathrm{~m}$ & $1.0 \mathrm{~km}$ & $5 \mathrm{~km}$ & $10 \mathrm{~km}$ & Mean \\
\hline \multirow{5}{*}{ 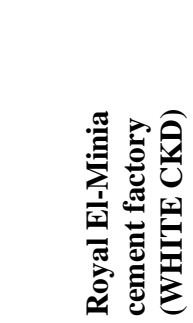 } & Northern & 1.80 & 1.69 & 1.12 & 0.90 & 0.30 & 0.10 & 0.99 \\
\hline & Southern & 1.50 & 1.15 & 0.88 & 0.10 & 0.09 & 0.05 & 0.63 \\
\hline & Eastern & 1.55 & 1.18 & 1.00 & 0.80 & 0.09 & 0.04 & 0.78 \\
\hline & Western & 1.59 & 1.40 & 0.99 & 0.50 & 0.07 & 0.02 & 0.76 \\
\hline & Mean & 1.61 & 1.36 & 0.99 & 0.58 & 0.14 & 0.05 & \\
\hline \multirow{5}{*}{ 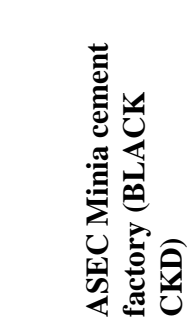 } & Northern & 2.90 & 2.40 & 1.50 & 0.12 & 0.05 & 0.01 & 1.16 \\
\hline & Southern & 2.89 & 2.40 & 1.44 & 0.13 & 0.07 & 0.02 & 1.16 \\
\hline & Eastern & 2.91 & 2.45 & 1.51 & 0.15 & 0.07 & 0.03 & 1.19 \\
\hline & Western & 2.90 & 2.40 & 1.51 & 0.12 & 0.05 & 0.02 & 1.17 \\
\hline & Mean & 2.90 & 2.41 & 1.49 & 0.13 & 0.06 & 0.02 & \\
\hline
\end{tabular}

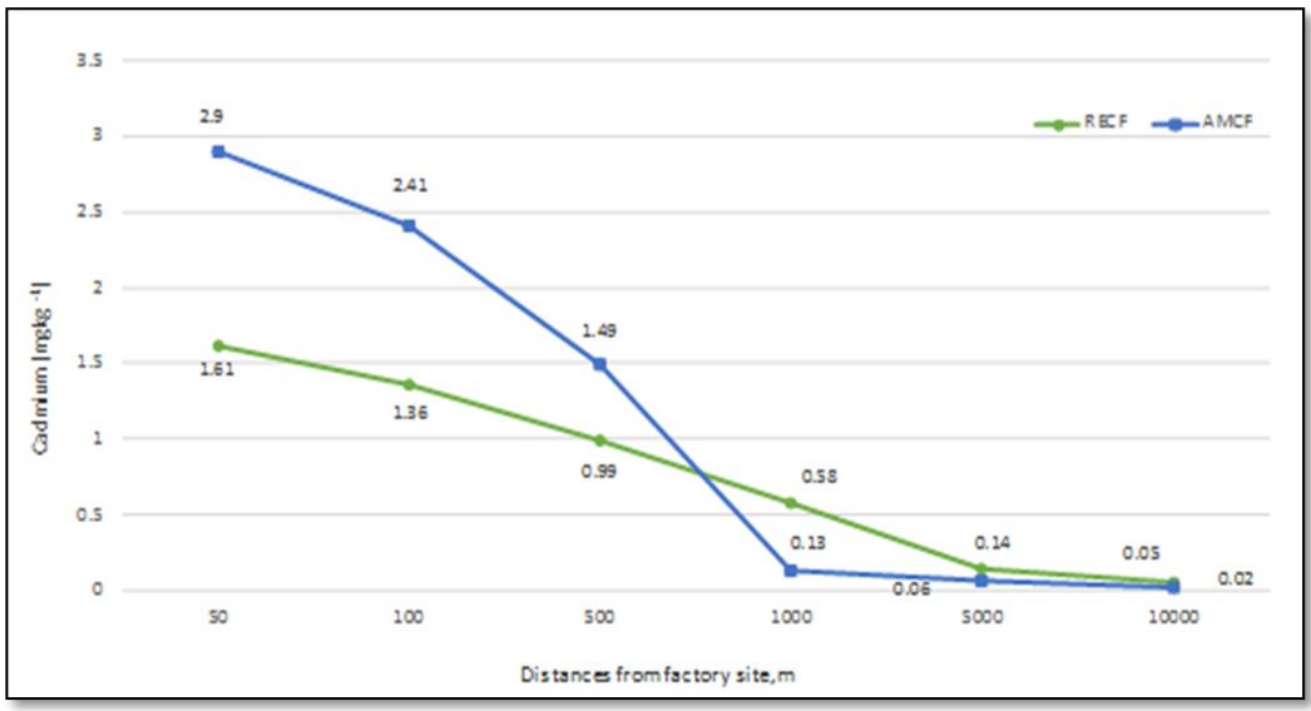

Figure 4: Spatial distribution of the mean value of soil Cd around the two cement factories 
The highest values of cadmium concentration in the soil are below the allowable concentration of cadmium in the arable soil according to the used guidelines. Thus, the site of Northern direction around the RECF and the site of Eastern direction around the $\mathrm{AMCF}$ at a monitoring distance of $50 \mathrm{~m}$ are classified as safe cadmium level sites.

\section{References}

[1] Abd El-Aleem, S.; Abd El-Aziz, M.A.; Heikal, M.; and El-Diamony, H. (2005). Effect of cement kiln dust substitution on chemical and physical properties and compressive strength of Portland and slag cements. The Arabian. Journal for Science and Engineering, Vol.30, No. 2B, pp. 263-273.

[2] Adaska, W.S. and Taubert, D.H. (2008). Beneficial uses of cement kiln dust. Presented at 2008 IEEE/PCA $50^{\text {th }}$ Cement Industry Technical Conf., Miami, FL, May 19-22, 2008, pp.1-19.

[3] Awashthi, S.K. (2000). Prevention of food adulation Act No. 37 of 1954. Central and State rules as amendment for 1999. IWD Edition. Ashoka Law House. New Delhi.

[4] Bhalerao, S.A.; Sharma, A.S.; and Poojari, A.C. (2015). Toxicity of nickel in plants. International Journal of Pure and Applied Bioscience, 3 (2), pp.345-355.

[5] Dong, J.; Mao, W.H.; Zhang, G.P.; Wu, F.B.; and Cai, Y. (2007). Root excretion and plant tolerance to cadmium toxicity: a review. Plant Soil Environ., 53 (5): pp.193-200.

[6] European Commission Director General Environment (ECDGE) (2010). Heavy metals and organic compounds from wastes used as organic fertilizers. Final Rep., July. WPA Consulting Engineers Inc. Ref. Nr. TEND AML/2001/07/20, pp.73-74. Online available at:

http://ec.earopa.eu/environment waste/compost/pdf/hm finalreport.pdf.

[7] ISO, 11047. (1998). Soil Quality: Determination of cadmium, chromium, cobalt, copper, lead, manganese, nickel, and zinc in aqua regia extracts of soilflame and electrothermal atomic absorption spectrometric methods.

[8] Jackson, M. L. (1973). Methods of chemical analysis. Prentic Hall., EngleWood Cliffs, N. T. J.

[9] Kloke, A. (1982). Re-use of sludges and treated waste water in agriculture. Wat. Sci. Techn. 14: pp.61-72

[10] Kunal; Siddique, R.; and Rajor, A. (2012). Use of cement kiln dust in cement concrete and its leachate characteristics: Review. Resources, Conservation and Recycling 61, pp. 59-68, Elsevier. Contents lists available at Sciverse Science Direct. Journal homepage:www.elsevier.com/locate/resconrec. [11] Mandal, A. and Voutchkov, M. (2011). Heavy metals in soils around the cement factory in Rockfort, Kingston, Jamaica. International Journal of Geosciences, 2, pp.48-54. Scientific Research.

[12] Naik, T.R.; Canpolat, F.; and Chun, Y. (2003). Uses of CKD other than for flue gas desulfurization. Center for by-products utilization, A CBU Report for Holcim (US), Report No. CBU-2003-35, REP-529, College of Engineering and Applied Science, The University of Wisconsin, Milwaukee, pp.1-33.

[13] Olowoyo, J.O.; Mugivhsa, L.L.; and Busa, N.G. (2015). Trace metals in soil and plants around a cement factory in Pretoria, South Africa. Pol.J. Environ. Siud. Vol. 24, No.5, pp.2087-2093.

[14] Page, A. L.; Miller, R. H.; and Keeney, D. R. (eds.) (1982). Methods of soil analysis. Part 2: Chemical and biological properties. Agronomy 9, $2^{\text {nd }}$ edition, Am. Soc. Agron., Madison, Wisconsin, USA.

[15] Pourrut, B.; Shahid, M.; Dumat, C.; Winterton, P.; and Pinelli, E. (2011). Lead uptake, toxicity, and detoxification in plants. Reviews of Environmental Contamination and Toxicology, Springer Verlag, Vol. 213, pp.113-136. ISSN 0179-5953. Online: available at: https://hal.archives-ouvertes.fr/hal-00717188. [16] Rahman, M. K.; Rehman, S.; and Al-Amoudi, O. S. B. (2011). Literature review on cement kiln dust usage in soil and waste stabilization and experimental investigation. IJRRAS, Vol. 7, Issue 1, April 2011, pp.77-87. Web Site: www.arpapress.com/volumes/vol7Issue1/IJJRAS 7112.PDF.

[17] Scianna, J. (2002). Salt-affected soils: Their causes, measure, and classification. Hort. Note No.5, Plant Materials Program, pp.1-3.

[18] Shnizai, Z. (2012). Contaminated land assessment and recommended remediation. Dockland site report, contaminated Land Remediation Company, Research Gate. Online available at:

https://www.reserchgate.net/publication/325713383. Access date: 8 September 2019.

[19] Wang, M.; Bai, Y.; Chen, W.; Markert, B.; Peng, C.; and Ouyang, Z. (2012). A GIS technology based potential eco-risk assessment of metals in urban soils in Bejing, China. Environmental pollution, 161: pp.235-242. 